\title{
Sejarah Hukum Lingkungan di Indonesia
}

\author{
Nafi' Mubarok \\ \begin{tabular}{l|l} 
nafi.mubarok@gmail.com & $\begin{array}{l}\text { VIN Sunan Ampel } \\
\text { Jf. A. Yani 117 Sura6aya }\end{array}$
\end{tabular}
}

\begin{abstract}
In conjunction with the development of contemporary Islamic law in Muslim countries, the question that frequently arises is about the formalization of Islamic law (taqnin). In Indonesia, the aspirations of Islamic Law's codification, particularly concerning its implementation crystallized into three forms; (1) formal (2) substantive, and (3) essential. One of the experts of Islamic law in Indonesia who concerned about the development of Islamic law was Sjechul Hadi Permono. This paper aims to explain the significance of Sjechul Hadi Permono's Legal Thought about Zakat. According to Sjechul Hadi Permono, the discourse on the people's welfare that is the burden of the state will always become a hot topic. Unfortunately, this problem has nerver been investigated based on the Islamic conception of welfare and the idea of Islam as an instrument of refom in society. This is a formula Sjechul Hadi tries to offer that zakat if properly managed will offer a solution to the welfare problem.
\end{abstract}

Keywords: Sjechul Hadi Permono, Development of Islamic Law, Zakat.

\begin{abstract}
Abstrak: Tulisan ini hadir dengan tujuan untuk memperoleh pamahaman yang komprehensif pada berbagai perangkat hukum yang terkait dengan lingkungan hidup, dengan memahami hukum lingkungan dari aspek sejarahnya. Hal ini dikarenakan bahwa hukum itu tidaklah dibuat, akan teapi tumbuh dan berkembang di dalam masyarakat. Kesimpulan dari tulisan ini ada. Pertama, bahwa sejarah pengaturan Hukum Lingkungan di Indonesia bisa diklasifikasikan pada tiga periode. Pertama, masa Hindia Belanda, kedua masa Jepang, dan ketiga masa setelah kemerdekaan. Kedua, bahwa sesudah Indonesia merdeka telah hadir tiga peraturan perundangundangan tentang lingkungan hidup, yaitu: (1) Undangundang No. 4 Tahun 1982 tentang Ketentuan-ketentuan Pokok Pengelolaan Lingkungan Hidup (UULH), (2) Undang-undang No. 23 Tahun 1997 tentang Pengelolaan Lingkungan Hidup (UUPLH), dan (3) Undang-undang No.
\end{abstract}


32 Tahun 2009 tentang Perlindungan dan Pengelolaan Lingkungan Hidup (UUPPLH). Masing-masing undangundang tersebut memiliki cirikhas dan karakteristik yang berbeda-beda, meskipun secara garis besar pada dasarnya undang-undang yang hadir setelahnya senantiasa hadir sebagai undang-undang yang menyempurnakan undangundang yang sebelumnya.

Kata kunci: sejarah hukum lingkungan dan hukum lingkungan Indonesia

\section{Pendahuluan}

Lingkungan hidup merupakan anugerah Allah SWT. yang harus dijaga, dilestarikan dan ditumbuh-kembangkan kapasistasnya agar supaya tetap bisa menjadi sumber penunjang hidup untuk manusia dan makhluk hidup lainnya, dan juga demi keberlangsungan dan meningkatkan kualitas hidup. ${ }^{1}$ Oleh karena itu hak untuk memperoleh lingkungan hidup yang sehat dan baik bersifat sama untuk seluruh manusia, bahkan untuk seluruh mahluk hidup yang di muka dunia. Di balik kesamaan hak tersebut, tentunya terdapat kewajiban atas semua manusia untuk menjaga dan melestarikan fungsi lingkungan hidup tersebut.

Terkait hal tersebut, M. Hasan Ubaidillah menyatakan bahwa: Manusia sebagai khalifah Allah di bumi telah diberikan "lisensi" untuk mengelola alam dan memanfaatkannya untuk memenuhi berbagai kebutuhan, dari yang profan seperti pemenuhan hajat hidup, sampai yang sakral seperti menjadi media untuk beribadah kepada sang Pencipta. Setiap bagian dari alam dan lingkungan yang diciptakan Allah SWT. tidak ada yang percuma. Semua telah didesain lengkap dengan manfaat dan kegunaannya masing-masing, untuk keberlangsungan hidup manusia. ${ }^{2}$

Indonesia yang memiliki wilayah yang luas tentunya juga memiliki berbagai problem lingkungan hidup yang

1 Muhammad Amin Hamid, "Penegakan Hukum Pidana Lingkungan Hidup dalam Menanggulangi Kerugian Negara," Legal Pluralism 6, no. 1 (Januari 2016): 88.

2 M. Hasan Ubaidilah, "Fiqh al-Bỉah (Formulasi Konsep al-Maqāṣid alSharỉah dalam Konservasi dan Restorasi Lingkungan)," Jurnal Al-Qānūn 13, no. 1 (Juni 2010): 26. 
sangat kompleks dan sangat urgent untuk mendapatkan perhatian secara serius. Tentunya adanya pencemaran dan kerusakan lingkungan di Indonesia ini akan memberikan dampak buruk bagi kehidupan rakyat Indonesia. ${ }^{3}$ Bahkan kerusakan dan pencemaran lingkungan hidup ini terlihat terus semakin mengenaskan dan memprihatinkan, dan terjadi di mana-mana. ${ }^{4}$ Apalagi kerusakan ini sudah membahayakan kehidupan tiap makhluk hidup, termasuk kehidupan generasi di masa mendatang. ${ }^{5}$

Sedangkan di sisi lain, Indonesia mempunyai peranan yang sangat penting terhadap kesinambungan ekosistem dunia, sebagai salah satu paru-paru dunia, kelestarian lingkungan hidup di Indonesia sangat penting, di samping itu negara-negara dunia sangat berkepentingan, dimana perusahaan negara tersebut melakukan eksploitasi terhadap sumber daya alam kita tanpa memperhatikan kelestarian lingkungan yang membawa dampak rusaknya lingkungan, beragam bencana menimpa masyarakat dan lingkungan hidup akibat limbah industri, wajah pengelolaan limbah di Indonesia seolah mencerminkan buruknya perhatian pemerintah terhadap kualitas hidup manusia. ${ }^{6}$

Secara global, Laode M. Syarif dan Kadek Sarna menyatakan, banjir bandang, tanah longsor, kebakaran hutan, hilangnya keanekaragaman hayati di darat dan di lautan, penipisan lapisan ozon, pemanasan global dan perubahan iklim, kekeringan, naiknya permukaan laut, tercemarnya sungai, air tanah, danau dan laut, tercemarnya udara dan timbulnya macam penyakit baru adalah hanya sebagian kecil dari akibat kerusakan lingkungan yang makin hari makin mengancam kelangsungan hidup seluruh

3 Nafi' Mubarok, "Penegakan Hukum Pidana Lingkungan di Indonesia," Al-Jinâyah: Jurnal Hukum Pidana Islam 5, no. 1 (Juni 2019): 2.

4 Ashabul Kahfi, "Kejahatan Lingkungan Hidup," Jurnal al-Daulah 3, no. 2 (Desember 2014): 207.

5 Hamid, "Penegakan Hukum Pidana Lingkungan Hidup dalam Menanggulangi Kerugian Negara," 90-91.

6 Elvie Wahyuni, "Penyelesaian Sengketa Lingkungan Hidup di Luar Pengadilan," Al-Ihkam IV, no. 2 (Desember 2009): 278. 
makhluk bumi. Pendeknya, permasalahan lingkungan semakin hari semakin menakutkan. Karena seiring dengan perkembangan industri dan pertambahan jumlah penduduk yang tak terkontrol khususnya di berbagai negara berkembang, kualitas lingkungan dunia semakin memprihatinkan, bahkan ada yang tidak dapat diperbaiki dan dipulihkan kembali seperti sediakala. ${ }^{7}$

Oleh karena itu, perlu penanggulangan terhadap bencana ekologi yang kini sedang melanda dunia, terutama Indonesia, baik yang bersifat teknis, ekonomis, politik, hukum, maupun sosial-budaya. ${ }^{8}$ Dalam konteks semisal inilah lahir hukum lingkungan dimana tujuannya bertujuan guna mengatur perilaku dan tindak-tindak manusia yang terkait dengan lingkungannya. ${ }^{9}$

Ini baik berupa diatur dalam aspek hukum perdatanya, aspek hukum pidananya maupun aspek hukum administrasinya. Ini bertujuan agar manusia bisa terhindar dari berbagai hal yang bisa menimbulkan kerugian dan kerusakan, di samping juga untuk melindungi manusia itu sendiri. Bentuknya dengan membuat perangkat hukum yang diharapkan bisa mencegah dan menanggulangi kerusakan dan pencemaran lingkungan. Dengan kata lain jikalau telah terjadi perusakan dan pencemaran lingkungan, maka diperlukan aturan hukum guna memulihkan dan mengembalikan lingkungan tersebut pada kondsi semua.

Bisa juga dikatakan bahwa, pada dasarnya hukum lingkungan memiliki dua fungsi, yaitu mengatur perilaku manusia dalam mengelola lingkungan dan sekaligus

7 Laode M. Syarif dan Andri G. Wibisana, Hukum Lingkungan: Teori, Legislasi dan Studi Kasus (Jakarta: USAID, 2015), 2.

8 Ubaidilah, "Fiqh al-Bỉah (Formulasi Konsep al-Maqāṣid al-Sharỉ'ah dalam Konservasi dan Restorasi Lingkungan)," 27.

9 Pada hakikatnya hukum mengandung ide-ide atau konsep-konsep yang abstrak yang dibuat untuk mengatur kehidupan manusia. Di dalam ide atau konsep yang abstrak ini terdapat ide tentang keadilan, kepastian, dan kemanfaatan sosial. Sebagaimana ditegaskan Gustav Radbruch, bahwa hukum harus memenuhi tiga nilai dasar, yaitu: keadilan, kegunaan, dan kepastian hukum. Lihat: Satjipto Rahardjo, Ilmu Hukum (Bandung: Citra Aditya Bakti, 1991), 19. 
memberikan perlindungan terhadap lingkungan itu sendiri. ${ }^{10}$

Selain itu, dapat dikatakan bahwa sebenarnya hukum lingkungan internasional yang modern baru berkembang sesudah usainya Perang Dunia II, meskipun secara spesifik dan dapat dijadikan patokan adalah sesudah Konferensi Stockholm yang diselenggarakan pada tahun 1972. Penyematan "modern" disini dikarenakan baru pada saat itulah masyarakat internasional menyadari bahwa hanya terdapat satu dunia saja, sebagaimana tema dalam konferensi tersebut, yaitu "One Worid Only". Dengan demikian, dunia dipandang sebagai satu sistem yang utuh, meskipun dengan berbagai ukuran wilayah yang menjadi syarat wujud nyata dari suatu negara hingga dunia ini terpilah-pilah. Walaupun begitu, dengan kesadaran lingkungan yang muncul dalam Konferensi Stockholm ini, maka disepakati bahwa sudah waktunya tidak lagi memandang dunia ini secara sektoral (terpisah-pisah) menurut wilayah dari tiap-tiap negara, namun sudah wajib dioandang sebagai suatu kesatuan yang utuh yang perlu ditumbuh kembangkan dan dilestarikan guna terpiliharanya unsur-unsur kehidupan yang beraneka ragam yang ada di dalamnya. ${ }^{11}$

Dengan kata lain, bahwa dalam rangka mewujudkan kesejahteraan rakyat, hukum lingkungan merupakan instrumen administrasi negara dalam perlindungan dan pengelolaan lingkungan hidup. Hukum lingkungan menjadi pedoman dalam rangka perlindungan dan pengelolaan lingkungan hidup tersebut. Norma perlindungan dan pengelolaan lingkungan hidup menjadi pedoman dalam penyelenggaraan perizinan bidang lingkungan hidup.

10 Muhammad Akib, "Pergeseran Paradigma Penegakan Hukum Lingkungan: dari Mekanistik-Reduksionis ke Holistik-Ekologi," Jurnal Masalahmasalah Hukum 43, no. 1 (Januari 2014): 125.

11 Frans Likadja, "Perkembangan Hukum Lingkungan Internasional (Kaitannya dengan kepentingan Indonesia)," Hukum dan Pembangunan, Juni 1990, 228. 
Hal tersebut bisa difahami bahwa secara global factor penyebab tumbuhnya kesadaran lingkungan dan kebutuhan terhadap instrument hukum sudah berkembang dengan begitu pesatnya, dan tidaklah terkait dengan fungsi hukum sebagai sarana pengendalian dan perlindungan dan kepastian hukum untuk masyarakat saja. Namun, yang lebih penting lagi bahwa diperlukan terdapatnya "a tool of social engineering" (sarana pembangunan) yang bisa berperan sebagai "agent of change" atau "agen of development". 12

Tercatat sebagai negara hukum, negara Indonesia telah mengeluarkan berbagai kebijakan dan instrument hukum yang terkait dengan lingkungan hidup, dengan selalu berupaya melakukan perbaikan pada instrument hukum yang ada. Ini bisa dilihat bahwa pada pada tanggal 11 Maret 1982 telah disahkan Undang-Undang Nomor 4 Tahun 1982 tentang Ketentuan-ketentuan Pokok Pengelolaan Lingkungan Hidup (UU-LH). Kemudian UU-LH ini diganti untuk disempurnakan dengan Undang-undang Nomor 23 Tahun 1997 tentang Pengelolaan Lingkungan Hidup (UU-PLH) pada tanggal 19 September 1997. Terakhir pada tanggal 3 Oktober 2009 telah disahkan Undangundang No. 32 Tahun 2009 tentang Perlindungan dan Pengelolaan Lingkungan Hidup.

Secara historis Indonesia adalah negara yang memberikan perhatian lebih terhadap lingkungan. Terutama dari aspek hukumnya. Ini terlihat dari turut berperan serta Indonesia dalam konferensi Stockholm 1972 dengan menganjukan pikiran berupa Indonesia's Country Report, suatu dokumen resmi yang semula di sampaikan oleh forum ECAFE Seminar on Development and Environtment di Bangkok, tanggal 17-23 Agustus 1971.13

Di sisi lain, The International Covenant on Economical and Social Rights telah disusun dan disepakati

12 Ashabul Kahfi, "Jaminan Konstitusional Terhadap Hak atas Lingkungan Hidup di Indonesia," Jurnal al-Daulah 2, no. 2 (Desember 2013): 146.

13 Siti Sundari Rangkuti, Hukum Lingkungan dan Kebijaksanaan Lingkungan Nasional (Surabaya: Airlangga University Press, 2000), 60. 
sebagai bagian dari Hukum HAM Internasional dengan tujuan satu-satunya guna melindungi hak-hak asasi manusia sehingga manusia bisa hidup sebagai manusia secara seutuh, bebas, aman, terlindungi dan sehat. Hak untuk hidup sebagai hak yang paling asasi tidaklah akan pernah bisa digapai selain dengan seluruh hak-hak dasar yang perlukan pada saat manusia hidup, semisal "hak untuk bekerja, makan, rumah, kesehatan, pendidikan, dan budaya" bisa tercukupi dan tersedia untuk tiap orang. Senyampang dengan maksud yang mendasar ini, maka dibuatlah instrumen HAM Internasional yang memberi perlindungan, baik pada individu ataupun pada kelompok, terkait hak-hak ekonomi, sosial, dan budaya yang dituangkan dalam CESCR 1966. CESCR secara global memberikan pengakuan kepada hak untuk memperoleh pekerjaan, hak untuk memperoleh pendidikan, hak untuk memperoleh kehidupan yang layak, hak atas lingkungan yang sehat, serta hak atas pengembangan budaya. ${ }^{14}$

Dalam konteks inilah tulisan ini hadir. Maksudnya tulisan ini hadir dalam rangka diperlukannya pamahaman yang komprehensif pada berbagai perangkat hukum yang terkait dengan lingkungan hidup. Salah satunya dengan memahami hukum lingkungan dari aspek sejarahnya. Hal ini dikarenakan bahwa hukum itu tidaklah dibuat, akan teapi tumbuh dan berkembang di dalam masyarakat, sebagaimana yang dipaparkan oleh pelopor mazhab Sejarah Hukum, Von Savigni. ${ }^{15}$ Harapannya kita bisa menilai dari sisi sejarah, tentang keberadaan hukum. Karena selama ini muncul berbagai tesis, terutama dalam hukum lingkungan, bahwa hukum, seperti sarang laba-laba, menangkap serangga-serangga kecil dan membiarkan yang besar-besar lolos). Hukum hanya mampu menjerat pelanggaran yang kecil, sementara kejahatan lingkungan

14 Kahfi, "Jaminan Konstitusional Terhadap Hak atas Lingkungan Hidup di Indonesia," 143-44.

15 Sebagaimana dikutip oleh Nafi' Mubarok. Lihat: Nafi' Mubarok, "Sejarah Hukum Perkawinan Islam di Indonesia," Jurnal Al-Hukama' 2, no. 2 (Desember 2012): 140 . 
yang besar seperti dicontohkan dalam kasus di atas ia tidak berdaya. ${ }^{16}$

Jelasnya bahwa tulisan ini akan mendeskrpsikan sejarah hukum lingkungan di Indonesia, dengan memaparkan dan menjelaskan berbagai perangkat hukum atau undang-undang di bidang lingkungan hidup yang pernah dan sedang berlaku di Indonesia, selanjutnya menguraikan pokok-pokok dan inti dari berbagai undangundang tersebut, dan disertai dengan membandingkann dengan undang-undang yang sebelumnya dan setelahnya.

\section{Periodesasi Hukum Lingkungan di Indonesia}

Pada dasarnya di Indonesia sudah dikenal organisasi yang berhubungan dengan lingkungan hidup, dimana sudah ada lebih dari sepuluh abad yang lalu. Ini bisa dilihat pada prasasti Jurunan tahun 876 Masehi diketahui adanya jabatan "Tuhalas" yakni pejabat yang mengawasi hutan atau alas, yang kira-kira identik dengan jabatan petugas Perlindungan Hutan dan Pelestarian Alam (PHPA). Kemudian prasasti Haliwagbang pada tahun 877 Masehi menyebutkan adanya jabatan "Tuhaburu" yakni pejabat yang mengawasi masalah perburuan hewan di Hutan. ${ }^{17}$

Tercatat dalam sejarah bahwa pengelolaan lingkungan hidup di Indonesia sudah dilakukan dan diatur dalam kaidah yuridis normatif. Dan itu dimulai sejak masa Hindia Belanda, masa Jepang dan masa Kemerdekaan. Masing-masing memiliki cirikhas yang berbeda-beda selaras degan sudut pandang dan sangat terkait dengan "kebijakan pembangunan lingkungan hidup" yang dicanangkan saat itu. Meskipun begitu, secara global bisa disimpulkan bahwa terdapat berbagai hal yang mempengaruhi tingkat kepedulian pada pengelolaan lingkungan hidup yang diwujudkan pada perangkat hukum. Yaitu faktor-faktor semisal kondisi politik, situasi sosial

16 Satjipto Rahardjo, Lapisan-lapisan dalam Studi Hukum (Malang: Bayu Media, 2009), 111.

17 Muhammad Erwin, Hukum Lingkungan dalam Sistem Kebijaksanaan Pembangunan Lingkungan Hidup (Bandung: Refika Aditama, 2011), 2. 
budaya dan ekonomi, serta kualitas sumber daya manusia hingga isu globalisasi.

Sehingga, sejarah hukum dalam bidang lingkungan dapat diklasifikasikan pada tiga periode sebagai berikut:

1. Masa Hindia Belanda

Peraturan perundang-undangan di bidang lingkungan yang ada sejak masa Hindia Belanda pertama kali diatur terkait perikanan, mutiara, dan perikanan bunga karang. Yaitu Peraturan Gubernur Jenderal Indenburg pada tanggal 29 Januari 1916 (Stb. 1916 No. 157) yang bernama Parelvisscherij, Sponservisscherijordonantie. Di dalamnya salah satunya diatur tentang "melakukan perikanan terhadap hasil laut", yang dijelaskan sebagai "tiap usaha dengan alat apapun juga untuk mengambil hasil laut dari laut dalam jarak tidak lebih dari tiga mil-laut inggris dari pantai-pantai Hindia Belanda (Indonesia)".18

Selanjutnya adalah Hinder-ordonnantie (Stbl. 1926 No. 226, yang diubah/ditambah, terakhir dengan Stbl. 1940 No. 450), yaitu Ordonansi Gangguan. ${ }^{19}$ Kemudian Bedrijfsreglemenigsordonnantie 1934 (Stbl. 1938 No. 86 jo. Stbl. 1948 No. 224) dalam bidang perusahaan. Berikutnya Natuurhermingsordonnantie 1941 (Stbl. 1941 No. 167), yaitu ordonansi tentang perlindungan alam.

2. Masa Jepang

Pada masa pendudukan Jepang, peraturan perundang-undangan di bidang lingkungan hidup hampir tidak dikeluarkan. Hanya satu, yaitu Osamu S Kanrei No. 6, suatu peraturam terkait larangan menebang pohon Aghata, Alba dan Balsem tanpa izin Gunseikan. Dimungkinkan bahwa pelarangan dalam undag-undang tersebut guna menjaga tiga jenis pohon tersebut, dikarenakan kayunya ringan namun sangat

18 Koesnadi Hardjasoemantri dan Harry Supriyono, Hukum Lingkungan (Jakarta: Universitas Terbuka, 2006), 24.

19 Erwin, Hukum Lingkungan dalam Sistem Kebijaksanaan Pembangunan Lingkungan Hidup, 3. 
kuat. Ketiga kayu tersebut merupakan bahan baku membuat pesawat peluncur (gliders), sedangkan pada masa itu pesawat peluncur sering dipagai guna mengangkut logistik tentara. ${ }^{20}$

3. Masa setelah kemerdekaan

Tidak bisa dipungkiri bahwa perkembangan dalam bidang lingkungan hidup di dunia internasional telah memberikan pengarauh ke Indonesia sebagai salah satu peserta dalam "Konferensi Stockholm". Kelihatannya Indonesia agak tertinggal dalam "pengembangan hukum lingkungan", dikarenakan baru setelah 10 tahun sejak adanya "Deklarasi Stockholm" Indonesia baru mempunyai instrument hukum lingkungan secara mandiri, yaitu Undang-undang Nomor 4 Tahun 1982 tentang Ketentuan-ketentuan Pokok Pengelolaan Lingkungan Hidup. Meskipun dalam rentang tahun 1972 dan 1982 sudah tidak sedikit berbagai upaya dilakukan guna megembangkan "Hukum Lingkungan", bentuknya dengan melakukan berbagai kegiatan dalam rangka menginfenatarisasi berbagai ketentuan perundang-undangan yang lama guna disesuaikan dengan perkembangan yang sedang terjadi. ${ }^{21}$

Pada dasarnya, dalam periode sudah cukup banyak diterbitkan berbagai undang-undang yang berkaitan dengan bidang lingkungan. Namun masih bersifat sektoral. Antara lain: (1) Undang-undang No. 5 Tahun 1960 tentang Peraturan Dasar Pokok-pokok Agraria; (2) UU No. 44 Prp. Tahun 1960 tentang Pertambangan Minyak dan gas Bumi; (3) UU No. 5 Tahun 1967 tentang Ketentuan-ketentuan Pokok Kehutanan; (4) UU No. 11 Tahun 1967 tentang Ketentuan-ketentuan Pokok Pertambangan; dan (5) UU No. 11 Tahun 1974 tentang Pengairan. $^{22}$

20 Hardjasoemantri dan Supriyono, Hukum Lingkungan, 25.

${ }^{21}$ Likadja, "Perkembangan Hukum Lingkungan Internasional (Kaitannya dengan kepentingan Indonesia)," 237.

22 Hardjasoemantri dan Supriyono, Hukum Lingkungan, 26. 
Babak baru pengaturan pengelolaan sumber daya alam dan lingkungan secara nasional diawali dengan diadakannya "Rapat Pengelolaan Lingkungan Hidup dan Pencegahan Pencemaran" oleh Menteri Negara Penertiban Aparatur Negara (PAN) pada tahun 1971. Selanjutnya dalam rangka persiapan Konferensi Stockholm diadakan seminar "Pengelolaan Lingkungan Hidup dan Pembangunan Nasional" pada 15-18 Mei 1972 di Bandung. Kemudian dibentuk "Panitia Perumus dan Rencana Kerja bagi Pemerintah di Bidang Pengembangan Lingkungan Hidup", yang diketuai oleh MenPan/Wakil Ketua BAPPENAS dan bersekretariat di LIPI, yang merupakan kelanjutan dari Konferensi Stockholm. ${ }^{23}$ Panitia ini dibentuk dengan Keputusan Presiden No. 16/1972. Tugasnya menyusun, membuat inventarisasi dan rencana kegiatan bagi pemerintah di bidang pengembangan lingkungan hidup. ${ }^{24}$ Panitia ini berhasil merumuskan program pembangunan lingkungan dalam wujud Bab 4 dalam Repelita II berdasarkan butir 10 Pendahuluan BAB III GBHN 19731978.

Selanjutnya dalam GBHN tahun 1978 digariskan tindak lanjutnya guna melakukan pembinaan pengelolaan lingkungan hidup. Buahnya dalam Kabinet Pembangunan III untuk pertama kalinya diangkat Menteri tersebut adalah Menteri Negara Pengawasan Pembangunan dan Lingkungan Hidup, yang bertugas mengkoordinasikan aparatur Pemerintah dalam pengelolaan sumber daya alam dan lingkungan hidup. Sebagai Menteri PPLH telah diangkat Prof. Dr. Emil Salim, guru besar Ekonomi pada Universitas Indonesia.

${ }^{23}$ Deklarasi Stockholm yang mengandung banyak asas kebijaksanaan dapat dipakai sebagai acuan dan sangat bermanfaat terhadap pengembangan hukum lingkungan nasional dan internasional. Lihat: Likadja, "Perkembangan Hukum Lingkungan Internasional (Kaitannya dengan kepentingan Indonesia)," 238.

24 Rangkuti, Hukum Lingkungan dan Kebijaksanaan Lingkungan Nasional, 60. 
Dalam periode ini juga telah hadir instrument hukum yang secara komplet dan menyeluruh mengatur lingkungan hidup. Yaitu Undang-undang No. 4 Tahun 1982 tentang Ketentuan-ketentuan Pokok Pengelolaan Lingkungan Hidup (UU-LH). Selanjutnya undangundang ini digantikan oleh Undang-undang No. 23 Tahun 1997 tentang Undang-undang Pokok Lingkungan Hidup (UU-PLH). Dan terakhir, digantikan oleh UndangUndang Nomor 32 Tahun 2009 tentang Perlindungan dan Pengelolaan Lingkungan Hidup (UU-PPLH). ${ }^{25}$

\section{Perbandingan berbagai Peraturan Perundang- undangan tentang Lingkungan Hidup di Indonesia Undang-undang No. 4 Tahun 1982 Tentang Ketentuan- ketentuan Pokok Pengelolaan Lingkungan Hidup (UU- LH)}

Sejarah dari pembentukan undang-undang ini diawali dengan menteri kehakiman membentuk tim teknis penyusun RUU pencegahan dan penanggulangan pencemaran laut pada tanggal 31 Maret 1975. RUU ini diharapkan sebagai awal Indonesia membenahi hukum lingkungan secara konsepsional. ${ }^{26}$

Akhirnya lahir Undang-undang No. 4 Tahun 1982 tentang Ketentuan-ketentuan Pokok Pengelolaan Lingkungan Hidup (UU-LH) pada tanggal 11 Maret 1982. Undang-undang ini terdiri dari (9) sembilan bab dan (24) dua puluh empat pasal. ${ }^{27}$

Pada dasarnya UULH 1982 merupakan sumber hukum formal (sekaligus sebagai payung pertama) dalam

${ }^{25}$ Kahfi, "Jaminan Konstitusional Terhadap Hak atas Lingkungan Hidup di Indonesia," 146.

26 Rangkuti, Hukum Lingkungan dan Kebijaksanaan Lingkungan Nasional, 62.

27 Sistematika dari UU-LH ini adalah: Ketentuan Umum (Bab I: Pasal 1 dan 2), Asas dan Tujuan (Bab II: Pasal 3-4), Hak, Kewajiban dan Wewenang (Bab III: Pasal 5-10), Perlindungan Lingkungan Hidup (Bab IV: Pasal 11-17), Kelembagaan (Bab V: Pasal 18-19), Ganti Kerugian dan Biaya Pemulihan (Bab VI: Pasal 20-21), Ketentuan Pidana (Bab VII: Pasal 22), Ketetuan Peralihan (Bab VIII: Pasal 23), dan Ketentuan Penutup (Bab IX: Pasal 24) 
tataran perundang-undangan di Indonesia dalam konteks hukum modern, sekaligus menandai era pembidangan hukum baru yaitu Hukum Lingkungan. Berbagai landasan dan argument dipakai untuk menghadirkan undang-undang ini. 28

Pengaturan lingkungan hidup dalam UU-LH ini sangat sederhana. Ini terlihat bahwa "ketentuan umum" hanyalah menjelaskan 14 hal. Sedangkan terkait pengertian Lingkungan Hidup, Pasal 1 no 1 dari UU-LH menyebutkan: "Lingkungan Hidup adalah kesatuan ruang dengan semua benda, daya, keadaan dan makhluk hidup, termasuk didalamnya manusia dan perilakunya, yang mempengaruhi kelangsungan perikehidupan dan kesejahteraan manusia serta makhluk hidup lainnya".

Selanjutnya, dalam UU-LH ini terdapat perbedaan antara "pencemaran lingkungan" dengan "perusakan lingkungan". Pencemaran lingkungan, sebagaimana dalam Pasal 1 no. 7, didevinisikan dengan: "masuknya atau dimasukannya makhluk hidup, zat, energi dan atau komponen lain ke dalam lingkungan dan atau berubahnya tatanan lingkungan oleh kegiatan manusia atau oleh proses alam, sehingga kualitas lingkungan menjadi kurang atau tidak berfungsi lagi sesuai dengan peruntukannya." Sedangkan perusakan lingkungan, sebagaimana dalam Pasal 1 no. 8, didevinisakan sebagai: "tindakan yang menimbulkan perubahan langsung atau tidak langsung terhadap sifat-sifat fisik dan atau hayati lingkungan, yang mengakibatkan lingkungan itu kurang atau tidak berfungsi lagi dalam menunjang pembangunan yang berkesinambungan."

Sedangkan asas dari UU-LH, sebagaimana disebutkan dalam Pasal 3, adalah: "Pengelolaan lingkungan hidup berasaskan pelestarian kemampuan lingkungan yang serasi dan seimbang untuk menunjang pembangunan yang

${ }^{28}$ Kahfi, "Jaminan Konstitusional Terhadap Hak atas Lingkungan Hidup di Indonesia,” 146. 
berkesinambungan bagi peningkatan kesejahteraan manusia."

Dan tujuan dari UU-LH, sebagaimana disebutkan dalam Pasal 4, adalah:

"Pengelolaan lingkungan hidup bertujuan:

a. Tercapainya keselarasan hubungan antar manusia dengan lingkungan hidup sebagi tujuan membangun manusia indonesia seutuhnya.

b. Terkendalinya pemnfaatan sumber daya secara bijaksana.

c. Terwujudnya manusia indonesia sebagai pembina lingkungan hidup.

d. Terlaksananya pembangunan berwawasan lingkungan untuk kpentingan generasi sekarang dan mendatang.

e. Terlindunginya negara terhadap dampak kegiatan diluar wilayah negara yang menyebabkan kerusakan dan pencemaran lingkungan."

UU-LH ini dalam hal "Ketentuan Pidana" hanya memuat satu pasal, yaitu Pasal 22. Jenis tindak pidananya adalah "perbuatan yang menyebabkan rusaknya lingkungan hidup atau tercemarnya lingkungan hidup". Jikalau dilakukan dengan sengaja maka ancaman pidananya berupa penjara maksimal 10 tahun dan/atau denda maskimal Rp.100.000.000,- (seratus juta rupiah). ${ }^{29}$ Akan tetapi jikalau dilakukan karena culpa (kealpaan), maka ancaman pidanaya berupa kurungan maksimal 1 tahun dan/atau denda maksimal Rp. 1.000.000,- (satu juta rupiah). ${ }^{30}$

\section{Undang-undang Nomor 23 Tahun 1997 tentang Pengelolaan Lingkungan Hidup (UU-PLH)}

Pada tanggal 19 September 1997 telah disahkan Undang Undang No. 23 Tahun 1997 tentang Pengelolaan Lingkungan Hidup (UU-PLH), yang merupakan penyempurna dari undang-undang sebelumnya (UU-LH).

${ }^{29}$ Sebagaimama ketentuan dalam Pasal 22 ayat (1).

30 Sebagaimama ketentuan dalam Pasal 22 ayat (2). 
Ini terlihat dengan semakin komplet dan komprehensipnya pengaturan dan juga semakin banyaknya pasal-pasal dalam undang-undang ini.

UU-PLH terdiri dari 9 bab dan 52 Pasal. ${ }^{31}$ Kelebihan UUPLH ini dibandingkan dengan UULH bisa dilihat dari cakupannya yang lebih luas. Dalam Bab I Ketentuan Umum dijelaskan 25 hal, yang selanjutnya dalam 25 hal tersebut dijelaskan 14 hal dalam Ketentuan Umum.

Sedangkan UU-PLH menjelaskan pengertian lingkungan hidup dalam Pasal 1 (1) dengan menyatakan: "Lingkungan hidup adalah kesatuan ruang dengan semua benda, daya, keadaan, dan makhluk hidup, termasuk manusia dan perilakunya, yang mempengaruhi kelangsungan perikehidupan dan kesejahteraan manusia serta makhluk hidup lain."

Sedangkan tentang Pengelolaan lingkungan, Pasal 1 no. 2 dari UU-PLH menyatakan: "Pengelolaan lingkungan hidup adalah upaya terpadu untuk melestarikan fungsi lingkungan hidup yang meliputi kebijaksanaan penataan, pemanfaatan, pengembangan, pemeliharaan, pemulihan, pengawasan, dan pengendalian lingkungan hidup."

Terkait dengan Ketentuan Pidana dalam UU-PLH bisa dikatakan jauh lebih lengkap dan rinci jika dibanding dengan ketentuan pidana dalam UU-LH. Dalam UU-PLH juga terbagi menjadi delik materiil dan delik formil. Delik materiilnya adalah "secara melawan hukum dengan sengaja melakukan perbuatan yang mengakibatkan pencemaran dan/atau perusakan lingkungan hidup". Ancaman pidananya berupa penjara maksimal 10 tahun dan denda maksimal Rp. 500.000.000,00; ${ }^{32}$ dan apabila berakobat

31 Sistematika UU-PLH ini adalah: Ketentuan Umum (Bab I: Pasal 1-2), Asas, Tujuan dan Sasaran (Bab II: Pasal 3-4), Hak, Kewajiban dan Peran Masyarakat (Bab III: Pasal 5-7), Wewenang Pengelolaan Lingkungan Hidup (Bab IV: Pasal 813), Pelestarian Fungsi Lingkungan Hidup (Bab V: Pasal 14-17), Persyaratan Penaatan Lingkungan Hidup (Bab VI: Pasal 18-29), Penyelesaian Sengketa Lingkungan Hidup (Bab VII: Pasal 30-39), Penyidikan (Bab VIII: Pasal 40-47), Ketentuan Pidana (Bab IX: Pasal 48), Ketentuan Peralihan (Bab X: Pasal 49), dan Ketentuan Penutup (Bab XI: Pasal 50-52)

32 Sebagaimana dalam Pasal 41 ayat (1) 
pada kematian atau luka berat maka ancaman pidananya berupa penjara maksimal 15 tahun dan denda maksimal Rp. 750.000.000.00. ${ }^{33}$ Sedangkan delik formil dalam UUPLH adalah "melakukan suatu perbuatan padahal mengetahui atau sangat beralasan untuk menduga bahwa perbuatan tersebut dapat menimbulkan pencemaran dan/atau perusakan lingkungan hidup atau membahayakan kesehatan umum atau nyawa orang lain", maka ancaman pidananya berupa penjara maksimal 6 tahun dan denda maksimal Rp. 300.000.000,00.34 Sedangkan pada ayat (2) dari Pasal tersebut dijelaskan terkait perbuatan "informasi palsu" yang ancaman pidananya sama dengan ayat (1). Jika tindak pidana tersebut berakibat pada kematian seseorang atau luka berat, maka ancaman pidanaya berupa penjara maksimal 9 tahun dan denda aksimal Rp. 450.000.000,00.35

Sayangnya pada UU-PLH ini terlihat telah memposisikan penegakan hukum pidana hanyalah sebagai upaya terakhir (ultimum remidium), akibatnya isi dari penegakan sanksi pidana dalam UU-PLH ini tidaklah dominan. Asas ultimum remedium ini pun dalam penjelasannya juga ternyata sangat kurang jelas dan tegas. ${ }^{36}$

Dalam UUPLH ini dikenal adanya kewenangan pengawasan secara atribusi diberikan kepada Menteri berdasarkan Pasal 22 ayat (1). Ketentuan ini bertujuan untuk memberikan wewenang yang lebih tegas kepada Menteri Negara Lingkungan Hidup (MNLH) untuk melakukan pengawasan. ${ }^{37}$

UU-PLH juga mengatur terkait upaya penyelesaian sengketa lingkungan hidup, dimana bisa diselesaikan

33 Sebagaimana dalam pasal 41 ayat (2)

34 Sebagaimana dalam Pasal 43 ayat (1).

35 Sebagaimana dalam Pasal 43 ayat (3).

36 So Woong Kim, "Kebijakan Hukum Pidana Dalam Upaya Penegakan Hukum Lingkungan Hidup," Jurnal Dinamika Hukum 13, no. 3 (September 2013): 416.

37 Kartono, "Penegakan Hukum Lingkungan Administratif dalam Undangundang Perlindungan dan Pengelolaan Lingkungan Hidup," Jurnal Dinamika Hukum 9, no. 3 (September 2009): 251. 
dengan menggunakan dua cara. Pertama, penyelesaian sengketa di luar pengadilan dan kedua penyelesaian sengketa melalui pengadilan. Akan tetapi, upaya penyelesaian sengketa di luar pengadilan ini tidak berlaku terhadap tindak pidana lingkungan hidup.

Hal tersebut di atas sebagaimana dijelaskan dalam Pasal 30 yang berbunyi:

1) Penyelesaian sengketa lingkungan hidup dapat ditempuh melalui pengadilan atau di luar pengadilan berdasarkan pilihan secara sukarela para pihak yang bersengketa.

2) Penyelesaian sengketa di luar pengadilan sebagaimana dimaksud pada ayat (1) tidak berlaku terhadap tindak pidana lingkungan hidup sebagaimana diatur dalam Undangundang ini.

3) Apabila telah dipilih upaya penyelesaian sengketa lingkungan hidup di luar pengadilan, gugatan melalui pengadilan hanya dapat ditempuh apabila upaya tersebut dinyatakan tidak berhasil oleh salah satu atau para pihak yang bersengketa.

Selain itu, di dalam UU-PLH juga dimuat ketentuan tentang akses public terkait penegakan hukum lingkungan dalam bidang keperdataan. Bentuknya diwujudkan dalam dua bentuk. Pertama yaitu dengan penegakan lingkungan di luar pengadilan, yang meliputi sukarela, non-pidana, tidak terbatas pada ganti kerugian, jasa pihak ketiga dan lembaga penyedia. Sedangkan kedua yaitu dengan pengekan lingkungan di dalam pengadilan, yang meliputi class action, legal standing NGO, gugatan perdata biasa, strict liability dan hak gugat instansi pemerintah. ${ }^{38}$ Hal tersebut sebagaimana dijelaskan dalam Pasal 37 ayat (1) dan (2), serta Pasal 38 ayat (1).

Bunyi dari Pasal 37 adalah:

1) Masyarakat berhak mengajukan gugatan perwakilan ke pengadilan dan/atau melaporkan ke penegak hukum 280 .

38 Wahyuni, "Penyelesaian Sengketa Lingkungan Hidup di Luar Pengadilan," 
mengenai berbagai masalah lingkungan hidup yang merugikan perikehidupan masyarakat.

2) Jika diketahui bahwa masyarakat menderita karena akibat pencemaran dan/atau perusakan lingkungan hidup sedemikian rupa sehingga mempengaruhi perikehidupan pokok masyarakat, maka instansi pemerintah yang bertanggung jawab di bidang lingkungan hidup dapat bertindak untuk kepentingan masyarakat.

Sedangkan bunyi Pasal 38 ayat (1) adalah: "Dalam rangka pelaksanaan tanggung jawab pengelolaan lingkungan hidup sesuai dengan pola kemitraan, organisasi lingkungan hidup berhak mengajukan gugatan untuk kepentingan pelestarian fungsi lingkungan hidup."

Sayangnya setelah berlaku sekitar 12 tahun menjadi paying hukum bagi Lingkungan Hidup Indonesia, dalam kenyataannya UU-PLH ini dianggap tidak berhasil mengemban misi "pelestarian" dan "pembangunan berkelanjutan dan berwawasan lingkungan". Ini bisa dilihat dari deretan panjang terkait berbagai kenyataan yang siap untuk dianalisa guna menyingkap kegagalan dari UU-PLH ini. ${ }^{39}$

\section{Undang-undang Nomor 32 Tahun 2009 tentang Perlindungan dan Pengelolaan Lingkungan Hidup (UU- PPLH)}

Pada tanggal 3 Oktober 2009 disahkan Undangundang Nomor 32 Tahun 2009 tentang Perlindungan dan Pengelolahan Lingkungan Hidup (UU-PPLH). UU-PPLH ini dianggap sebagai penyempurnaan dan pelengkap dari UUPLH yang sudah ada sebelumnya. UU-PPLH ini menjadi harapan baru untuk kelestarian dan keberlanjutan lingkungan hidup di Indonesia. Penguatan dan idealisme UU-PPLH ini oleh banyak pihak dianggap sebagai terobosan yang sangat mendasar secara filosofis dan sangat tidak berlebihan apalagi bersifat politis. Lebib-lebih UU-PPLH ini

39 Kahfi, "Jaminan Konstitusional Terhadap Hak atas Lingkungan Hidup di Indonesia," 147. 
adalah jelmaan dari "jaminan konstitusional" yang diberikan oleh UUD 1945 Amandemen. ${ }^{40}$

Latar belakang lahirnya Undang - Undang Nomor 32 Tahun 2009 tentang Perlindungan dan Pengelolaan Lingkungan Hidup (UU PPLH) adalah maraknya kasus yang berkenaan dengan lingkungan hidup yang semakin harisemakin memperihatinkan, salah satunya terkait permasalahan di hutan. Banyaknya kasus kebakaran hutan, pencurian kayu-kayu di hutan Indonesia atau yang lebih dikenal dengan illegal longing case yang tidak tertangani dengan baik menandakan bahwa undang-undang yang merupakan instrument pemerintah dalam rangka merawat, menjaga, dan dan menangkal segala mara bahaya yang telah dan mungkin akan terjadi tidaklah efektif bekerja. ${ }^{41}$

UU-PPLH ini terdiri dari 17 bab dan 124 pasal. ${ }^{42}$ Ketentuan Umum dari UU-PPLH ini menjelaskan 39 hal. Lingkungan hidup oleh UU-PPLH ini, sebagaimana dalam Pasal 1 no. 1, dinyatakan dengan: "Lingkungan hidup adalah kesatuan ruang dengan semua benda, daya, keadaan, dan makhluk hidup, termasuk manusia dan perilakunya, yang mempengaruhi alam itu sendiri, kelangsungan peri kehidupan, dan kesejahteraan manusia serta makhluk hidup lain."

Selain itu, UUPLH ini tidak hanya menggunakan istilah "pengelolaan lingkungan" saja, akan tetapi juga

40 Kahfi, 144.

41 Suparto Wijoyo dan Wilda Prihatiningtyas, "Problematika Penegakan Hukum Lingkungan di Indonesia," Airlangga Development Journal 1, no. 2 (2016): 2 .

42 Sistematika dari UU-PPLH adalah Ketentuan Umum (Bab I: Pasal 1), Asas, Tujuan, dan Ruang Lingkup (Bab II: Pasal 2-4), Perencanaan (Bab III: Pasal 5-11), Pemanfaatan (Bab IV: Pasal 12), Pengendalian (Bab V: Pasal 13-56), Pemeliharaan (Bab VI: Pasal 57), Pengelolaan Bahan Berbahaya dan Beracun Serta Limbah Bahan Berbahaya dan Beracun (Bab VII: Pasal 58-61), Sistem Informasi (Bab VIII: asal 62), Tugas Dan Wewenang Pemerintah dan Pemerintah Daerah (Bab IX: Pasal 63), Hak, Kewajiban, dan Larangan (Bab X: Pasal 65-69), Peran Masyarakat (Bab XI: Pasal 70), Pengawasan dan Sanksi Administratif (Bab XII: Pasal 76-83), Penyelesaian Sengketa Lingkungan (Bab XIII: Pasal 84-93), Penyidikan Dan Pembuktian (Bab XIV: Pasal 94-96), Ketentuan Pidana (Bab XV: Pasal 97-120), Ketentuan Peralihan (Bab XVI: Pasal 121), dan Ketentuan Penutup (Bab XVII: Pasal 124). 
menggunakan istilah "perlindungan dan pengelolaan lingkungan hidup". ${ }^{43}$

Dalam Pasal 4 dari UU-PPLH ini juga dimuat ketentuan terkait ruang lingkup perlindungan dan pengelolaan lingkungan hidup, yaitu: perencanaan, pemanfaatan, pengendalian, pemeliharaan, pengawasan dan penegakan hukum.

Kelebihan dari UU-PPLH 2009 dibandingkan dengan undang-undang sebelumnya, menurut Ashabul Kahpi, bahwa undang-undang ini sudah memberikan porsi yang lebih banyak terkait hak-hak lingkungan. Ini bisa dilihat dengan diakuinya delapan hak, baik yang bersifat hak sbubstantif maupun yang besifat hak prosedural. Tentunya ini dengan harapan akan lebih menjamin kelestarian lingkungan hidup, juga perlindungan terhadap hak-hak individu dan masyarakat, yang tentnya juga hak lingkungan itu sendiri. ${ }^{44}$

Menurut Muhammad Amin Hamid, bahwa alasan dibalik kehadiran UUPPLH ini adalah guna mensesuaikan dengan perkembangan zaman untuk terciptanya sustainable development. Tentunya ini harus ditindak lanjuti sampai tingkatan PERDA (peraturan daerah) dari tiap-tiap provinsi ataupun kota/kabupaten di seluruh Indonesia, yang materinya mengatur terkait berbagai problem lingkungan, dan tidak tanggung-tanggung, bahkan terdapat juga penjatuhan sanksi pidana yang sangat berat di dalamnya. Pidana yang semestinya adalah ultimum remedium dalam penegakan hukum, akan tetapi pada kasus hukum lingkungan ini fungsinya dikedepankan dan berubah menjadi "primum remedium", dikarenakan dipandang sangat efektif guna menangkal berbagai kasus yang terkait dengan perusakan lingkungan. Urgensitas

43 Dalam UU-PPLH ini "perlindungan dan pengelolaan lingkungan hidup" dijelaskan sebagai "upaya sistematis dan terpadu yang dilakukan untuk melestarikan fungsi lingkungan hidup dan mencegah terjadinya pencemaran dan/atau kerusakan lingkungan hidup yang meliputi perencanaan, pemanfaatan, pengendalian, pemeliharaan, pengawasan, dan penegakan hukum.

${ }_{44}$ Kahfi, "Jaminan Konstitusional Terhadap Hak atas Lingkungan Hidup di Indonesia," 145. 
digunakannya sanksi pidana dan dirubah menjadi "premium remedium" dikarenakan ketika penggunaan sanksi pidana menjadi "sampingan" atau "ultimum remedium" dalam menyelesaikan berbagai problem terkait dengan pencemaran lingkungan hidup, maka terlihat telah melahirkan berbagai kelemahan. ${ }^{45}$

Yang berbeda dengan UUPPLH adalah adanya satu jenis izin baru yang selama ini dihindari pemerintah, yaitu: izin lingkungan. Izin ini ternyata tidak diwajibkan kepada semua kegiatan/usaha yang berdampak bagi lingkungan. Tetapi hanya diwajibkan bagi kegiatan/ usaha yang wajib dilakukan Analisis Mengenai Dampak Lingkungan (Amdal) atau kegiatan yang wajib dilakukan kajian Rencana Pengelolaan Lingkungan atau Rencana Pemantauan Lingkungan (RKL-RPL). ${ }^{46}$

Aspek hukum pidana dalam UU-PPLH diatur pada bagian Ketentuan Pidana (Bab XV: Pasal 97-120). Yang pada intinya bahwa UU-PPLH dalam penggunaan sarana hukum pidana memberlakukan dua asas. Yaitu: pertama bahwa hukum pidana merupakan ulmitimum remedium (upaya terakhir), ini terkait dengan delik formil tertentu, yaitu penjatuhan pidana pada pelanggaran baku mutu air limbah, emisi, dan gangguan, ${ }^{47}$ sebagaimana dimuat dalam Pasal 100 dari UU-PPLH. Kedua bahwa penggunaan hukum pidana dengan asas premium remedium (mendahulukan pelaksanaan penegakan hukum pidana), dimana hal ini terkait dengan ketentuan selain dalam Pasal 100 dari UU-PPLH.

45 Hamid, "Penegakan Hukum Pidana Lingkungan Hidup dalam Menanggulangi Kerugian Negara," 92-93.

46 Kartono, Penegakan Hukum Lingkungan Administratif, hlm. 252.

47 Upaya perlindungan lingkungan dilakukan berdasarkan baku mutu lingkungan, baik berupa criteria kualitas lingkungan (ambient) maupun kualitas buangan atau limbah (effluent). Baku mutulingkungan hidup adalah ukuran batas atau kadar makhluk hidup, zat, energi, atau komponen yang ada atau harus ada dan/atau unsur pencemar yangditenggang keberadaannya dalam suatu sumber dayatertentu sebagai unsur lingkunganhidup. Baku mutu sebagai tolok ukur untuk menetapkan apakah lingkungan telah rusakatau apakah suatu kegiatan telah merusak lingkungan perlu dilaksanakan dan diacu dalam kegiatan pembangunan nasional. Lihat: Desni Bram, Politik Hukum Pengelolaan Lingkungan Hidup (Malang: Setara Press, 2013), 2. 
Dengan demikian, bahwa pengaturan tindak pidana lingkungan pada UUPPLH ini bisa dikatakan lebih tegas. Ini bisa dilihat dari penjatuhan sanksi pidana yang cukup berat yang diatur dalam UUPPLH ini. Oleh karenanya UUPPLH ini lebih menjamin kepastian hukum dan memberikan perlindungan terhadap hak setiap orang untuk mendapatkan lingkungan hidup yang baik dan sehat, Undang-Undang Nomor 32 Tahun 2009.48

Singkatnya UU-PPLH menyatakan bahwa delik lingkungan (yang merupakan perbuatan yang dilarang) adalah "mencemarkan atau merusak lingkungan". Sedangkan, jika ditinjau dari perumusan tindak pidana, dalam UUPPLH terdapat tindak pidana materiil dan tindak pidana formil. ${ }^{49}$ Akan tetapi, di samping itu terdapat juga delik yang jika diperhatikan lebih teliti mengandung makna selain masuk dalam kategori delik formal juga masuk dalam kategori delik materiil. Ini bisa dilihat dalam Pasal 98 ayat (2), (3) dan Pasal 99 ayat (2), (3) dari UUPPLH.

Selain itu, sebagaimana dijelaskan oleh Takdir Rahmadi, salah seorang Hakim Agung RI, bahwa kelebihan dari UU-PPLH dibanding dengan UU-PLH, sebagai berikut: 50 1. UU-PPLH mengadopsi asas-asas yang terdapat dalam Deklarasi Rio Tahun 1992 secara tegas, yaitu asas tanggung jawab negara, asas keterpaduan, asas kehatihatian, asas keadilan, asas pencemar membayar, asas partisipatif dan asas kearifan lokal.

2. UU-PLH lebih terdepan dalam memberikan perlindungan hukum pada perjuang hak-hak atas lingkungan hidup dari kemungkinan adanya tuntutan pidana dan gugatan perdata, sebagaiman dijelaskan dalam Pasal 66 dari UU-PPLH.

3. UU-PLH telah melakukan perubahan terkait "kewenangan penyidikan" dalam perkara-perkara

48 Kim, “Kebijakan Hukum Pidana Dalam Upaya Penegakan Hukum Lingkungan Hidup," 416.

${ }^{49}$ Kahfi, "Kejahatan Lingkungan Hidup," 211.

50 Takdir Rahmadi, "Perkembangan Hukum Lingkungan di Indonesia," t.t., http://www.mahkamahagung.go.id/rbnews.asp?bid=2949. 
lingkungan, sebagaiman dijelaskan dalam Pasal 94 ayat (6) dari UU-PPLH.

4. Instrument hukum pidana dalam UU-PLH bukanlah merupakan ultimum remedium (upaya terakhir) guna memidana para pelaku usaha yang telah menimbulkan berbagai masalah dalam bidang lingkungan hidup.

5. Secara tegas mengatur bahwa pertanggung-jawaban pidana berada di tangan pimpinan suatu badan usaha yang sudah mengakibatkan terjadinya pencemaran dan perusakan lingkungan hidup, sebagaiman dijelaskan dalam Pasal 116-119 dari UU-PPLH.

6. UU-PLH telah mengatur "delik materil" yang berlaku pada pejabat pemerintah yang berwenang dalam bidang pengawasan lingkungan, sebagaiman dijelaskan dalam Pasal 112 dari UU-PPLH.

Meskipun begitu, sebagaimana dikemukakan oleh Muhammad Adib, dalam UU=PPLH terdapat beberapa kelamahan. Dianataranya adalah terkait dengan instrumen ekonomik sebagai wujud dari the polluter pays principle. Dalam UU-PPLH lebih berorientasi kepada pungutan an sich ketimbang untuk pencegahan pencemaran lingkungan. Padahal pengenaan instrumen ekonomik yang tepat diharapkan mampu mendukung pemecahan masalah lingkungan. Ini bisa dibuktikan bahwa sanksi administrasi yang diatur dalam Pasal 76 ayat (2) UUPPLH-2009 tidak mengatur sanksi uang paksa sebagai alternatif jika sanksi paksaan pemerintahan sulit diterapkan. Padahal, kedua jenis sanksi tersebut secara teoretik sangat efektif untuk menghentikan pelanggaran lingkungan. ${ }^{51}$

\section{Penutup}

Setelah memperhatikan berbagai penjelasan sebelumnya, maka bisa disimpulkan hal-hal sebagai berikut:

51 Akib, "Pergeseran Paradigma Penegakan Hukum Lingkungan: dari Mekanistik-Reduksionis ke Holistik-Ekologi," 127. 
1. Bahwa sejarah pengaturan Hukum Lingkungan di Indonesia bisa diklasifikasikan pada tiga periode. Pertama, masa Hindia Belanda, kedua masa Jepang, dan ketiga masa setelah kemerdekaan.

2. Bahwa sesudah Indonesia merdeka telah hadir tiga peraturan perundang-undangan tentang lingkungan hidup. Pertama adalah Undang-undang No. 4 Tahun 1982 tentang Ketentuan-ketentuan Pokok Pengelolaan Lingkungan Hidup (UULH), kedua adalah Undangundang No. 23 Tahun 1997 tentang Pengelolaan Lingkungan Hidup (UUPLH), dan ketiga adalah Undangundang No. 32 Tahun 2009 tentang Perlindungan dan Pengelolaan Lingkungan Hidup (UUPPLH). Undangundang tersebut masing-masing memiliki cirikhas dan karakteristik yang tidak sama. Akan tetapi pada dasarnya undang-undang yang hadir setelahnya senantiasa hadir sebagai undang-undang yang menyempurnakan undang-undang yang sebelumnya. Sebagai contoh adalah UU-PPLH, dimana memilihi kelebihan jika dibandingkan dengan UU-PLH, yaitu: (1) telah mengadopsi asas-asas yang terdapat dalam Deklarasi Rio 1992, (2) lebih memberikan perlindungan hukum pada para pejuang hak atas lingkungan hidup, (3) terdapatnya perubahan terkait kewenangan pada proses penyidikan, (4) hukum pidana bukanlah sebagai ultimum remedium (upaya terakhir), (5) aanya pertanggung jawaban pidana pada pimpinan suatu badan usaha, dan (6) telah mengatur tindak pidana materil yang berlaku pada pejabat pemerintah.

\section{Daftar Pustaka}

Akib, Muhammad. "Pergeseran Paradigma Penegakan Hukum Lingkungan: dari Mekanistik-Reduksionis ke HolistikEkologi." Jurnal Masalah-masalah Hukum 43, no. 1 (Januari 2014).

Bram, Desni. Politik Hukum Pengelolaan Lingkungan Hidup. Malang: Setara Press, 2013. 
Erwin, Muhammad. Hukum Lingkungan dalam Sistem Kebijaksanaan Pembangunan Lingkungan Hidup. Bandung: Refika Aditama, 2011.

Hamid, Muhammad Amin. "Penegakan Hukum Pidana Lingkungan Hidup dalam Menanggulangi Kerugian Negara." Legal Pluralism 6, no. 1 (Januari 2016).

Hardjasoemantri, Koesnadi, dan Harry Supriyono. Hukum Lingkungan. Jakarta: Universitas Terbuka, 2006.

Kahfi, Ashabul. "Jaminan Konstitusional Terhadap Hak atas Lingkungan Hidup di Indonesia." Jurnal al-Daulah 2, no. 2 (Desember 2013).

-_- "Kejahatan Lingkungan Hidup." Jurnal al-Daulah 3, no. 2 (Desember 2014).

Kartono. "Penegakan Hukum Lingkungan Administratif dalam Undang-undang Perlindungan dan Pengelolaan Lingkungan Hidup." Jurnal Dinamika Hukum 9, no. 3 (September 2009).

Kim, So Woong. "Kebijakan Hukum Pidana Dalam Upaya Penegakan Hukum Lingkungan Hidup." Jurnal Dinamika Hukum 13, no. 3 (September 2013).

Likadja, Frans. "Perkembangan Hukum Lingkungan Internasional (Kaitannya dengan kepentingan Indonesia)." Hukum dan Pembangunan, Juni 1990.

Mubarok, Nafi'. "Penegakan Hukum Pidana Lingkungan di Indonesia." Al-Jinâyah: Jurnal Hukum Pidana Islam 5, no. 1 (Juni 2019).

- - - "Sejarah Hukum Perkawinan Islam di Indonesia." Jurnal Al-Hukama' 2, no. 2 (Desember 2012).

Rahardjo, Satjipto. Ilmu Hukum. Bandung: Citra Aditya Bakti, 1991.

- - - Lapisan-lapisan dalam Studi Hukum. Malang: Bayu Media, 2009.

Rahmadi, Takdir. "Perkembangan Hukum Lingkungan di Indonesia," "P.t. http://www.mahkamahagung.go.id/rbnews.asp?bid=294 9.

Rangkuti, Siti Sundari. Hukum Lingkungan dan Kebijaksanaan Lingkungan Nasional. Surabaya: Airlangga University Press, 2000.

Syarif, Laode M., dan Andri G. Wibisana. Hukum Lingkungan: Teori, Legislasi dan Studi Kasus. Jakarta: USAID, 2015. 
Ubaidilah, M. Hasan. "Fiqh al-Bīah (Formulasi Konsep al-Maqāṣid al-Shari'ah dalam Konservasi dan Restorasi Lingkungan)." Jurnal Al-Qānün 13, no. 1 (Juni 2010).

Wahyuni, Elvie. "Penyelesaian Sengketa Lingkungan Hidup di Luar Pengadilan." Al-Ihkam IV, no. 2 (Desember 2009).

Wijoyo, Suparto, dan Wilda Prihatiningtyas. "Problematika Penegakan Hukum Lingkungan di Indonesia." Airlangga Development Journal 1, no. 2 (2016). 